Хомич Іванна

викладач кафедри вікової та педагогічної психології Рівненського державного гуманітарного університету

ORCID iD: 0000-0001-8930-6572

DOI https://doi.org/10.35619/prap_rv.vi13.140

\title{
ФАКТОРНА СТРУКТУРА ОСОБИСТОСТІ МОЛОДШОГО ШКОЛЯРА
}

\begin{abstract}
Анотація. Стаття присвячена визначенню факторної моделі особистісних характеристик молодших школярів, компонентами якої виступатимуть інтегральні (латентні) особистісні фактори, які детермінують змістовий характер і специфіку уявлень молодших школярів про нормовідповідність власної поведінки. Вважаємо, щчо молодші школярі ще не можуть володіти повноцінною моральною поведінкою із внутрішньою моральною самодетермінацією, вони можуть лише оволодівати ї̈ моральними формами. Тому саме емпіричне вивчення розвитку нормовідповідної поведінки дітей молодтого шкільного віку та визначення інтегральних особистісних факторів дозволяє розширити знання про природу становлення структури особистості, з'ясувати ї̈ особливості та механізми розвитку. В результаті факторного аналізу ми виділили факторну модель особистісних характеристик молодших школярів. В структуру даної моделі увійшло шість інтегральних особистісних факторів. Виявлені закономірності дозволили нам зробити припущення, щзо специфічні особливості виявлених інтегральних особистісних факторів молодших школярів можуть виступати особистісними предикторами розвитку їх сочіально-психологічної компетентності у сфері нормовідповідності власної поведінки.
\end{abstract}

Ключові слова: молодший школяр, особистісні характеристики, особистісні фактори, нормовідповідність поведінки, уявлення про поведінку, факторна модель, факторизація ,соиіально-психологічна компетентність.

Постановка проблеми. Актуальною залишається проблема моральних аспектів поведінки молодших школярів. Тому визначення факторної моделі особистості в молодшому шкільному віці, компонентами якої виступають інтегральні особистісні фактори, має велике значення для розуміння змісту, характеру і специфіки уявлень молодших школярів про нормовідповідність власної поведінки.

Аналіз останніх досліджень 3 проблеми. У сучасних наукових дослідженнях розкриваються психологічні механізми формування моральної поведінки. Праці науковців, які досліджують моральні аспекти поведінки, мають на меті розкрити психологічні особливості розуміння молодшими школярами моральних норм, вимог, що лежать в основі особливого мотиву людських вчинків і є смисловим принципом регуляції поведінки (Корнєв, (1995); Мухина, (2004); Орбан-Лембрик, (2004). При цьому значна увага надається формуванню у школярів певної системи моральних знань як базисного елемента моральної свідомості та самосвідомості та важливого аспекту структури особистості.

Значна частина наукових досліджень присвячена проблемі нормативності як основній характеристиці поведінки молодшого школяра. Павелків, (2005) констатує, що усвідомлено закріплена, емоційно збагачена та апробована у поведінці моральна норма перетворюється на стійку якість особистості (с. 231). Підтримуємо думку Порохняк, (2014) про те, що необхідною умовою становлення особистості дитини є розвиток моральних якостей, почуттів і накопичення досвіду моральної поведінки (с. 393).

Виконані дослідження дають можливість виокремити деякі тенденції розвитку моральної поведінки та формування структури особистості. Вважаємо, що молодші школярі ще не можуть володіти повноцінною моральною поведінкою із внутрішньою моральною самодетермінацією, вони можуть лише оволодівати їі моральними формами. Саме емпіричне 
вивчення розвитку нормовідповідної поведінки дітей молодшого шкільного віку та визначення інтегральних особистісних факторів дозволяє розширити знання про природу становлення структури особистості.

Мета статті. Метою нашого повідомлення є визначення факторної структури особистості молодших школярів, компонентами якої виступають інтегральні особистісні фактори, що детермінують змістовий характер і специфіку уявлень молодших школярів про нормовідповідність власної поведінки. Згідно із сформульованою метою нашими завданнями є: аналіз останніх публікацій із проблематики нашої роботи, опис методів дослідження 3 метою конкретизації дослідницької позиції та здійснення емпіричного аналізу вказаної проблеми.

Виклад основного матеріалу дослідження. Дослідження проводилось на базі Рівненської гімназії «Гармонія», Рівненської класичної гімназії «Престиж» (м. Рівне), Луцьких загальноосвітніх шкіл I-III ступенів №5 i №8 (м. Луцьк) та Тернопільської загальноосвітньої школи I-III ступенів №19 (м. Тернопіль). Досліджуваними стали учні перших-четвертих класів у кількості 189 осіб.

Визначивши особистісні характеристики молодших школярів, нами було здійснено їх факторизацію з метою верифікації факторної моделі соціально-психологічної компетентності у сфері нормовідповідності власної поведінки. Вихідним емпіричним фактажем для факторизації стали змінні, виміряні за допомогою наступних психодіагностичних засобів: дитячий варіант 16-факторного особистісного тесту Кеттела, методика діагностики особистісних цінностей Журавльова, Журавльової, анкета-опитувальник для батьків, вихователів та вчителів для експертного оцінювання особистісних якостей молодших школярів та їх взаємовідносин 3 оточуючими. Передбачалося, що структурними компонентами факторної моделі виступатимуть інтегральні (латентні) особистісні фактори, які детермінуватимуть змістовий характер і специфіку (рівень розвитку) уявлень молодших школярів про нормовідповідність власної поведінки. Факторизація методом головних компонент (Principal Components) 3 наступним варімакс-обертанням (Varimax normalized) матриці психологічних шкал, дозволило отримати однозначно інтерпретовану факторну модель особистісних характеристик досліджуваних (табл. 1).

Як видно з таблиці, перший фактор, пояснюючи 19,0\% дисперсії ознак, відображає особистісні характеристики досліджуваних, які змістовно визначаються від'ємним полюсом однієї і додатнім полюсом семи психологічних шкал. Категоризація даного фактору дозволяє ідентифікувати його сутнісну основу, зміст якої визначає особистісна настанова оцінювати себе та інших через призму морально-етичних категорій і принципів.

3 найбільшою факторною вагою у цей фактор увійшли наступні психологічні шкали:

- «альтруїзм» $(0,859)$, як загальнолюдська цінність і принцип поведінки, який полягає у безкорисливому прагненні до діяльності на благо інших;

- «чесність» $(0,817)$, як одна з важливих загальнолюдських чеснот, моральна якість, що відображає одну з найважливіших вимог моральності;

- «сумлінність» $(0,778)$, як одна 3 важливих загальнолюдських чеснот, пов'язана 3 почуттям моральної відповідальності за свою поведінку, свої вчинки перед самим собою, людьми, суспільством;

- «справедливість» $(0,771)$, як людська цінність і принцип поведінки, який полягає у рівності між всіма;

- «терпимість» $(0,737)$, як здатність терпимо, поблажливо ставитись до чужих звичок, звичаїв, поглядів;

- «вихованість» $(0,690)$, як морально-етична характеристика людини, що полягає у вмінні адекватно поводитись у суспільстві (з іншими);

- «освіченість» $(0,669)$, як фактична наявність у людини істотного обсягу знань, що дозволяють їй дані знання застосовувати на практиці;

- «багатство» $(-0,631)$, як цінність, пов'язана 3 можливістю володіння матеріальними і нематеріальними благами в обсязі, більшому, ніж володіє більшість звичайних людей. 3 урахуванням знаку змінна багатство не є важливою і цінною для досліджуваних. 
Факторна модель особистісних характеристик молодших школярів

\begin{tabular}{|c|c|c|c|c|c|c|}
\hline \multirow{2}{*}{ Особистісні характеристики } & \multicolumn{6}{|c|}{ Фактори } \\
\hline & 1 & 2 & 3 & 4 & 5 & 6 \\
\hline Альтруїзм & .859 & & & & & \\
\hline Чесність & .817 & & & & & \\
\hline Сумлінність & .778 & & & & & \\
\hline Справедливість & .771 & & & & & \\
\hline Терпимість & .737 & & & & & \\
\hline Вихованість & .690 & & & & & \\
\hline Освіченість & .669 & & & & & \\
\hline Багатство & -.631 & & & & & \\
\hline широта поглядів & & .812 & & & & \\
\hline Незалежність & & .777 & & & & \\
\hline Наполегливість & & .726 & & & & \\
\hline тверда воля & & .647 & & & & \\
\hline Життєрадісність & & .543 & & & & \\
\hline Відповідальність & & .534 & & & & \\
\hline Сміливість & & .515 & & & & \\
\hline Ефективність у справах & & & .793 & & & \\
\hline Організаторські здібності & & & .757 & & & \\
\hline Взаємовідносини з іншими дітьми & & & .651 & & & \\
\hline Працелюбність & & & .529 & & & \\
\hline Підприємливість & & & .511 & & & \\
\hline Практичність & & & .503 & & & \\
\hline Емпатія & & & & .743 & & \\
\hline Чуйність & & & & .675 & & \\
\hline Емоційна реактивність & & & & -.619 & & \\
\hline Незворушність & & & & -.579 & & \\
\hline Агресивність & & & & -.511 & & \\
\hline Самоконтроль & & & & & .686 & \\
\hline Впевненість в собі & & & & & .654 & \\
\hline Самостійність & & & & & .620 & \\
\hline Екстраверсія & & & & & & .628 \\
\hline Оптимізм & & & & & & .577 \\
\hline
\end{tabular}

Якщо змістовно узагальнити психологічні шкали, що увійшли до першого фактору, то можна виділити спільну для них особливість - всі вони, в тій чи іншій мірі, характеризують виражений морально-етичний імператив у власній поведінці та ставленні до інших. Таким чином, змістовно узагальнюючи психологічні змінні, які увійшли до першого особистісного фактору, інтерпретуємо його як фактор «морально-ціннісного відношення» молодших школярів. Передбачається, що визначений особистісний фактор виступатиме детермінуючим чинником розвитку уявлень молодших школярів про нормовідповідність власної поведінки.

Другий фактор, пояснюючи 12,8\% дисперсії ознак, відображає особистісні характеристики молодших школярів, які змістовно визначаються додатнім полюсом семи психологічних шкал. Категоризація даного фактору дозволяє ідентифікувати його сутнісну основу, зміст якої визначає настанова досліджуваних на ствердження i прояв своєї особистісної позиції в житті.

3 найбільшою факторною вагою у цей фактор увійшли наступні психологічні шкали: 
- «широта поглядів» $(0,812)$, яка характеризує здатність володіти розвинутим розумом, терпимістю до різних проявів будь-чого;

- «незалежність» $(0,777)$, яка проявляється у можливості приймати самостійні рішення, спрямовані на задоволення власних бажань та інтересів і не потребує зовнішніх вказівок;

- «наполегливість» $(0,726)$, яка характеризує якість особистості, що дозволяє переслідувати віддалені, довготривалі цілі, для досягнення яких необхідно докладати великих зусиль;

- «тверда воля» $(0,647)$, яка характеризує силу характеру людини;

- «життерадісність» $(0,543)$, яка характеризує рису людини бадьоро і світло сприймати дійсність, радість до життя;

- «відповідальність» (0,534), яка виражає свідоме ставлення людини до вимог суспільної необхідності;

- «сміливість» $(0,515)$, яка виражає здатність у випадку виникнення небезпеки зберігати стійкість.

Змістовно узагальнюючи психологічні шкали, що увійшли до другого фактору, відмітимо спільну для них особливість - всі вони характеризують настанову на особистісне самоствердження i прояв своєї особистісної позиції. 3 огляду на це, можемо проінтерпретувати другий фактор як фактор «особистісного самоствердження».

Третій фактор, пояснюючи 10,8\% дисперсії ознак, відображає особистісні характеристики дітей молодшого шкільного віку, які змістовно визначаються додатнім полюсом шести психологічних шкал. Категоризація даного фактору дозволяє ідентифікувати його сутнісну основу, зміст якої характеризує особистісну настанову на відповідальне ставлення до справи та інших людей.

3 найбільшою факторною вагою у цей фактор увійшли наступні психологічні шкали:

- «ефективність у справах» $(0,793)$ - тип ціннісного ставлення людини, який визначає іiі прагнення досягнути позитивного результату у тому чи іншому виді діяльності або міжособистісній взаємодії;

- «організаторські здібності» $(0,757)$ - здібності людини, які проявляються у здатності правильно організувати діяльність певної групи;

- «взаємовідносини 3 іншими дітьми» $(0,651)$, характеризує цінність процесу спілкування і взаємовідносин з іншими дітьми;

- «працелюбність» $(0,529)$ - риса характеру людини, яка проявляється у любові до праці;

- «підприємливість» $(0,511)$ - риса характеру людини, яка проявляється у практичній кмітливості, здатності активно діяти, ініціативності;

- «практичність» $(0,503)$ - риса характеру людини, яка проявляється у діловитості, практичному ставленні до життя.

Таким чином, змістовно узагальнюючи змінні, які увійшли до третього особистісного фактору, інтерпретуємо його як фактор «ціннісного відношення до справ, обов 'язків та інших людей». Передбачається, що визначений інтегральний особистісний фактор виступатиме детермінуючим чинником розвитку соціально-психологічної компетентності молодших школярів у сфері нормовідповідності власної поведінки.

Перейдемо до інтерпретації четвертого фактору особистісної структури молодших школярів. Даний фактор, пояснюючи 8,1\% дисперсії ознак, формально визначається додатнім полюсом двох і від'ємним полюсом трьох психологічних шкал.

3 найбільшою факторною вагою у цей фактор увійшли наступні психологічні шкали:

- «емпатія» $(0,743)$, як здатність до розуміння відносин, почуттів, психічних станів іншої людини у формі співпереживання;

- «чуйність» $(0,675)$, як здатність людини тонко відчувати емоційний і душевний стан іншого і вміння допомогти йому; 
- «емоційна реактивність» $(-0,619)$, як ступінь неконтрольованості емоційних реакцій людини на будь-які подразники зовнішнього або внутрішнього характеру; з урахуванням знаку може свідчити про низьку емоційну збудливість (реактивність) та стриманість;

- «незворушність» $(-0,579), \quad 3$ урахуванням знаку характеризується як врівноваженість і холоднокровність;

- «агресивність» $(-0,511)$, характеризується афективними спалахами гніву чи злоби, спрямованими на об'єкт фрустрації, що з урахуванням знаку означає відсутність агресивних тенденцій у поведінці.

Змістовно узагальнюючи психологічні змінні, які увійшли до четвертого особистісного фактору, «маркуємо» його як фактор «емоційно-ціннісної направленості» досліджуваних. Можна припустити, що визначений інтегральний особистісний фактор виступатиме детермінуючим чинником розвитку соціально-психологічної компетентності молодших школярів у сфері нормовідповідності власної поведінки.

П’ятий фактор, виділений в ході факторизації масиву емпіричних даних, пояснюючи 7,1\% дисперсії ознак, формально визначається додатнім полюсом трьох психологічних шкал. Категоризація фактору дозволяє ідентифікувати його сутнісну основу, яка відображає особистісну настанову на високий рівень самоконтролю за своїми діями, вчинками, поведінкою.

3 найбільшою факторною вагою у цей фактор увійшли такі психологічні шкали:

- «самоконтроль» (0,686), протиставляється імпульсивності, як нездатності протистояти миттєвим бажанням;

- «впевненість в собі» $(0,654)$, впевнене прийняття і визначеність у рішеннях;

- «самостійність» $(0,620)$, як здатність самому ставити цілі і їх досягати.

Таким чином, змістовно узагальнюючи психологічні змінні, які увійшли до п'ятого фактору, «маркуємо» його як фактор «особистісного самоконтролю» досліджуваних. Передбачається, що визначений інтегральний особистісний фактор може лежати в основі розвитку соціально-психологічної компетентності молодших школярів у сфері нормовідповідності власної поведінки.

Перейдемо до змістової інтерпретації шостого особистісного фактору. Даний фактор, пояснюючи 6,5\% дисперсії ознак, відображає особистісні характеристики досліджуваних, які змістовно визначаються додатнім полюсом двох психологічних шкал. Категоризація даного особистісного фактору дозволяє ідентифікувати його сутнісну основу, зміст якої визначається відкритістю до світу, його позитивним сприйняттям.

3 найбільшою факторною вагою у цей фактор увійшли наступні шкали:

- «екстраверсія» $(0,628)$, яка характеризується зосередженістю інтересів особистості на зовнішніх об’єктах, високою ініціативністю;

- «оптимізм» $(0,577)$, що виражається у схильності людини бачити у всіх подіях тільки позитивні сторони.

Таким чином, змістовно узагальнюючи психологічні змінні, які увійшли до шостого фактору, визначаємо його як фактор «відкритості до світу». Можна передбачити, що визначений інтегральний особистісний фактор може виступати структурним компонентом розвитку соціально-психологічної компетентності молодших школярів у сфері нормовідповідності поведінки.

Підводячи підсумки, зазначимо, що результати факторного аналізу дозволили виділити факторну модель особистісних характеристик молодших школярів. В структуру даної моделі увійшло шість інтегральних факторів:

1) «морально-ціннісного відношення» (інформативність фактору - 19,0\%);

2) «особистісного самоствердження» (інформативність фактору - 12,8\%);

3) «иіннісного відношення до справ, обов'язків та інших людей» (інформативність фактору - 10,8\%);

4) «емоиійно-ичіннісної направленості» (інформативність фактору - 8,1\%);

5) «особистісного самоконтролю» (інформативність фактору - 7,1\%);

6) «відкритості до світу» (інформативність - 6,5\%). 
Отже, можна зробити припущення, що специфічні особливості виявлених інтегральних особистісних факторів молодших школярів можуть виступати особистісними предикторами розвитку їх соціально-психологічної компетентності у сфері нормовідповідності власної поведінки.

Висновки і перспективи подальших розвідок. Значущість емпіричного дослідження проблеми визначення факторної моделі особистісних характеристик молодших школярів полягає у тому, що компонентами даної моделі виступають інтегральні (латентні) особистісні фактори, які в свою чергу детермінують змістовий характер і специфіку уявлень молодших школярів про нормовідповідність власної поведінки. Більш грунтовну перевірку даного припущення буде здійснено у наступних наших дослідженнях.

\section{СПИСОК ПОСИЛАНЬ}

Бююль, А., Цефель П. (2005). SPSS: искусство обработки информации. Анализ статистических данных и восстановление скрытых закономерностей. Москва: ДиаСофтЮп.

Мишакова, Г. А. (2010). Психологические особенности нравственности младших школьников, воспитывающихся в различных сощиильно педагогических условиях. (Дис. канд. психол. наук). Самара.

Мухина, В. С. (2004). Возрастная психология: феноменология развития, детство, отрочество. Москва: Академия.

Орбан-Лембрик, Л. Е. (2004). Соціальна психологія. Київ: Либідь.

Павелків, Р. В. (2015). Розвиток моральної свідомості та самосвідомості в молодиому шкільному віці. (Дис. д-ра психол. наук). Рівненський державний гуманітарний університет. Рівне.

Порохняк, Д. С. (2013). Вікові особливості морального розвитку молодших школярів. Збірник наукових праць К-ПНУ ім. Івана Огієнка Інституту психології ім. Г. С. Костюка, 25, 393-403.

\section{REFERENCES}

Biuiul, A., \& Tsefel' P. (2005). SPSS: iskusstvo obrabotki informatsyi. Analiz statisticheskikh dannykh i vosstanovleniie skrytykh zakonomernostei [Information processing art. Statistical data analysis and hidden patterns restoration]. Moskva: DiaSoftYup. [in Russian].

Mishakova, H. A. (2010). Psikholohicheskiie osobennosti nravstvennosti mladshykh shkolnikov, vospityvaiushchykhsia $v$ razlichnykh sotsialno-pedahohicheskikh uslovyiakh [Morality psychological features of junior schoolchildren who are brought up in different social and pedagogical conditions]. (Dys. kand. psykhol. nauk). Samara. [in Russian].

Mukhina, V. S. (2004). Vozrastnaia psykholohiia: fenomenolohiia razvitiia, detstvo, otrochestvo [Developmental psychology: development phenomenology, childhood, adolescence]. Moskva: Akademiia. [in Russian].

Orban-Lembryk, L. E. (2004). Sotsialna psykholohiia [Social psychology] Kyiv: Lybid. [in Ukrainian].

Pavelkiv, R. V. (2015). Rozvytok moralnoi svidomosti ta samosvidomosti v molodshomu shkilnomu vitsi [Moral consciousness and self-consciousness development in junior schoolchild's age]. (Dys. d-ra psykhol. nauk). Rivne State Humanities University. Rivne. [in Ukrainian].

Porokhniak, D. S. (2013). Vikovi osoblyvosti moralnoho rozvytku molodshykh shkoliariv [Age peculiarities of junior schoolchildren moral development]. Zbirnyk naukovykh prats K-PNU im. Ivana Ohiienka Instytutu psykholohii im. H. S. Kostiuka, 25, 393-403. [in Ukrainian]. 


\title{
PERSONEL FACTOR STRUCTURE OF JUNIOR SCHOOLCHILD
}

Ivanna Khomych

Lecturer of Department of Lifespan \& Pedagogical Psychology Department of Rivne State University for the Humanities

ORCID iD: 0000-0001-8930-6572

DOI https://doi.org/10.35619/prap_rv.vi13.140

\begin{abstract}
The study deals with the model defining of junior schoolchild personal characteristics. It has been singled out such model components as integral (latent) personal factors that determine content character and specific features of junior schoolchild ideas if their behavior is in accordance with behavior norms. Herewith the author pays attention to the certain system formation of schoolchild's mental knowledge as a basic element of mental consciousness and selfconsciousness and the person's important structure aspect. It has been analyzed the mentioned issue and concluded that the essential precondition of child's personality becoming is the development of mental characteristics, feelings, and gaining of mental behavior experience. The author argues that junior schoolchild may not have control over full mental behavior with inner mental self-determination yet, they may only get control over its forms.

That is why empirical research of junior schoolchild behavior accordance with norms and personal integral factors defining makes it possible to widen knowledge about personal structure formation origin, single out its specific features and mechanisms of the development. As the result of factor analysis it has been singled out the factor model of junior schoolchild personal characteristics. The author includes six integral factors into given model structure. There are mental and valuable relations, personal self-assertion, valuable relations to the affairs, duties, and other people, emotional and valuable direction, personal self-control, open-mindedness to the world. Researched common factors gave a possibility to suggest that specific peculiarities of revealed junior schoolchild's integral personal factors might be presented as personal development predictors of their social and psychological competence in the sphere of the own behavior accordance with norms.

Key words: elemrntary-school student, characteristics of personality, personal factors, social behavior, concept of behavior, factor model, factorization, social and psychological competence
\end{abstract}

